\title{
PEMBERDAYAAN MASYARAKAT MELALUI PEMBENTUKAN \\ KADER TANGGAP STUNTING SEBAGAI UPAYA DETEKSI DINI DAN PENCEGAHAN STUNTING DI DESA CIKUNIR KECAMATAN SINGAPARNA KABUPATEN TASIKMALAYA \\ TAHUN 2019
}

\author{
OLEH : \\ Sinta Fitriani, S.KM,M.KM \\ Hariyani S S.KMM.KM, Erwina Sumartini, S.ST,M.Keb \\ Ade Rahmat, Amalia Siti Zahra,Agung NN, M.Jamaludin,Risma ,Nina Nurjannah \\ taniesa1571@gmail.com
}

STIKes Respati

\section{A. DASAR PEMIKIRAN}

Latar belakang program ini adalah Stunting (kerdil) merupakan kondisi dimana balita memiliki panjang atau tinggi badan yang kurang jika dibandingkan dengan umur. Kondisi ini diukur dengan panjang atau tinggi badan yang lebih dari minus dua standar deviasi median standar pertumbuhan anak dari WHO. Balita stunting termasuk masalah gizi kronik yang disebabkan oleh banyak faktor seperti kondisi sosial ekonomi, gizi ibu saat hamil, kesakitan pada bayi, dan kurangnya asupan gizi pada bayi. Balita stunting di masa yang akan datang akan mengalami kesulitan dalam mencapai perkembangan fisik dan kognitif yang optimal. (Kemenkes RI : 2018)

Pada tahun 2018, ditetapkan 100 kabupaten di 34 provinsi sebagai lokasi prioritas penurunan stunting. Jumlah ini akan bertambah sebanyak 60 kabupaten pada tahun berikutnya. Dengan adanya kerjasama lintas sektor ini diharapkan dapat menekan angka stunting di Indonesia sehingga dapat tercapai target Sustainable Development Goals (SDGs) pada tahun 2025 yaitu penurunan angka stunting hingga $40 \%$.

Berdasarkan data dari Dinas Kesehatan Kabupaten Tasikmalaya didapatkan bahwa wilayah Kecamatan Singaparna merupakan salah satu wilayah dengan prevalensi stunting pada bulan Februari tahun 2019 yaitu sebanyak 136 balita dengan status gizi sangat pendek dan 444 balita dengan status pendek. Dari 5 Desa Cikunir prevalensi kejadian stunting paling tinggi dengan 26 balita dengan status gizi sangat pendek dan 113 balita dengan ststus gizi pendek. Potensi kegiatan pemberdayaan di wilayah Desa Cikunir sangat besar, hal ini dikarenakan Pemerintahan Desa Cikunir sangat kooperatif dan focus pada kegiatan kesehatan salah satunya adalah issue stunting dan ODF. Dalam kegiatan Kabupaten sehat Bupati Tasikmalaya 
menyampaikan lokasi khusus untuk permsalahan stunting adalah wilayah Kecamatan Singaparna. Selain itu potensi lain yang memungkinkan untuk dapat menjadi pendukung program adalah ketersediaan kader aktifyang terdistribusi di 12 posyandu.

Dampak yang ditimbulkan stunting dapat dibagi menjadi dampak jangka pendek dan jangka panjang. Dampak Jangka Pendek meliputi Peningkatan kejadian kesakitan dan kematian; Perkembangan kognitif, motorik, dan verbal, pada anak tidak optimal; dan peningkatan biaya kesehatan. Dampak Jangka Panjangyang timbul : Postur tubuh yang tidak optimal saat dewasa (lebih pendek dibandingkan pada umumnya); Meningkatnya risiko obesitas dan penyakit lainnya; Menurunnya kesehatan reproduksi; Kapasitas belajar dan performa yang kurang optimal saat masa sekolah; dan Produktivitas dan kapasitas kerja yang tidak optimal.

Dalam penanganan stunting, Pemerintah Indonesia merumuskan 5 pilar penanganan stunting. Pada Pilar ke 4 berisi tentang Mendorong Kebijakan Akses Pangan Bergizi; Dalam rangka intervensi penanganan stunting di 2018, disasar 100 kabupaten/kota di seluruh Indonesia. Kementerian Desa, Pembangunan Daerah Tertinggal dan Transmigrasi pun terlibat aktif dalam upaya menekan angka stunting. Ragam penanganan stunting yang berhubungan dengan intervensi spesifik dan sensitif terkait stunting terwadahi lewat Peraturan Menteri Desa tentang Pemanfaatan Dana Desa. Lewat peraturan yang dikeluarkan tersebut, Warga Desa bisa terlibat aktif menghadirkan aneka kegiatan yang berhubungan upaya penanganan stunting. Kehadiran Dana Desa telah membangun 6.041 Pondok Bersalin Desa (Polindes), penyediaan 32.711unit air bersih, 82.356 unit sarana Mandi, Cuci dan Kakus (MCK). Berhasil pula membangun 13.973 Pos Pelayanan Terpadu (Posyandu), 21.357 unit bangunan PAUD (Pendidikan Anak Usia Dini).

Berdasarkan hal tersebut, tim pengusul telah melaksanakan berbagai kegiatan untuk mewujudkan Pemodelan DEBASTING (Desa Bebas Stunting) melalui pemberdayaan perempuan dan pendekatan budaya di Desa Cikunir Kecamatan Singaparna Kabupaten Tasikmalaya.

\section{B. TUJUAN}

1. Tujuan Umum Menurunkan kejadian stunting pada balita diwilayah Desa Cikunir Kecamatan Singaparna Kabupaten Tasikmalaya

2. Tujuan Khusus

a. Membentuk kader tanggap stunting Di Desa Cikunir Kecamatan Singaparna Kabupaten Tasikmalaya Tahun 2019.

b. Melaksanakan pelatihan kader tanggap stunting di Desa Cikunir Kecamatan Singaparna Kabupaten Tasikmalaya Tahun 2019. 


\section{SASARAN}

Sasaran dalam kegiatan pengembangan dan pemberdayaan masyarakat dalam pelatihan kader tanggap stunting adalah kader posyandu yang dipilih masing masing 2 orang dari 12 posyandu yang berada di Desa Cikunir .

Jumlah peserta yang mengikuti adalah 24 kader.

\section{WAKTU DAN TEMPAT PELAKSANAAN}

\begin{tabular}{|r|l|l|}
\hline No & \multicolumn{1}{|c|}{ Kegiatan } & \multicolumn{1}{c|}{$\begin{array}{c}\text { Waktu } \\
\text { Pelaksanaan }\end{array}$} \\
\hline 1. & $\begin{array}{l}\text { Pembentukan } \\
\text { Komunitasi kader } \\
\text { tanggap stunting }\end{array}$ & $\begin{array}{l}\text { 24 September } \\
2019\end{array}$ \\
\hline 2. & $\begin{array}{l}\text { Pelatiha kader } \\
\text { Tanggap stunting }\end{array}$ & $\begin{array}{l}17-18 \\
\text { Oktober 2019 }\end{array}$ \\
\hline
\end{tabular}

\section{E. HASIL KEGIATAN}

1. Kapasitas kader tanggap stunting

Peningkatan kemampuan kader dalam deteksi dini serta penggunaan SI CENTING mampu menjaring 4 orang tambahan balita stunting yang terdistribusi di Perum cinta raja 1 orang dan di Cilaja 1 terdapat 3 orang. Data balita stunting yang dihasilkan dari kegiatan pengukuran tinggi badan pada bulan November 2019 akan disampaikan ke petugas gizi puskesmas untuk ditindak lanjuti. Sementara keluarga yang menderita stunting sebanyak 22 keluarga telah diberikan edukasi melalui konseling keluarga oleh kader. Selain itu terdapat 5 Posyandu yang telah melaksanakan kegiatan penyuluhan pencegahan stunting di posyandu terhadap ibu hamil dan ibu balita.

\section{Peningkatan pengetahuan dan sikap}

Terjadi peningkatan pengetahuan dan sikap kader dengan hasil sebagai berikut : Rata rata nilai pengetahuan kader sebelum program PHBD adalah 7,17 dengan standar deviasi 1.606. sedangkan rata rata pengetahuan kader setelah mengikuti kegiatan PHBD adalah 13,54 dengan standar deviasi 0,884 . Hasil uji statistik didapatkan p value 0,000 artinya ada perbedaan yang signifikan antara pengetahuan kader sebeum dan sesudah mengikuti program PHBD.

Sehingga dapat disimpulkan bahwa ada pengaruh program PHBD dalam meningkatkan pengetahuan kader tanggap stunting dengan nilai t hitung 19,080 > dari t tabel 2,068. 
Berdasarkan data datas didapatkan bahwa negative ranks adalah 0 artinya tidak ada penurunan nilai sikap sebelum dan sesudah program PHBD. Sedangkan positive ranks adalah 24 artinya seluruh kader mengalami peningkatan nilai sikap sebelum dan sesudah program PHBD dengan mean rank adalah 12,50 dan sum of rank 300,00. Nilai ties dalam variable sikap adalah 0 artinya tidak ada nilai sikap yang sama antara sebelum dan sesudah program PHBD.

Berdasarkan output test statistic didapatkan nilai asymp.sig(2tailed) adalah $0,000<0,05$ artinya terdapat perbedaan yang signifikan antara nilai sikap kader sebelum dan sesudah program PHBD, yang berarti ada pengaruh yang signifikan dan posotif program PHBD terhadap perubahan sikap kader tanggap stunting.

Hasil advokasi yang diperoleh dikeluarkannya surat edaran Kepala Desa tentang program pecegahan stunting melalui kegiatan himbauan kepada ibu hamil dan ibu balita untuk mncukupi kebutuhan gizi, menghimbau ibu memberikan ASI eksklusif, memotivasi ibu balita dan ibu hamil untuk keposyandu dan gerakan membersihkan lingkungan.

Setelah adanya PHBD, dukungan para tokoh terhadap upaya pecegahan stunting terwujud dalam beberapa kegiatan berikut :

a. Surat edaran kepala desa tentang pencegahan stunting dengan nomor surat 011/XI/DS/2019

b. Gerakan opsih (kebersihan) lingkungan di 3 dusun

c. Terdapat tokoh agama yg penyuluhan tentang pencegahan stunting di dusun Pameungpeuk

d. Serta tokoh masyarakat yang menghimbau warga untuk ke posyandu setiap bulan.

3. Pelaksanaan pemberdayaan kader melalui gerobak gizi

Pelaksanaan kegiatan pemeberdayaan kader melalui kegiatan gerobak gizi akan dilaksanakan bulan Desember 2019. Tahapan yang sudah dilaksankan adalah musyawarah tehnik pelaksanan gerobak gizi dengan kesepakatan bahwa gerobak akan disediakan oleh desa yang terdistribusi di masing masing dusun. 
F. DOKUMENTASI
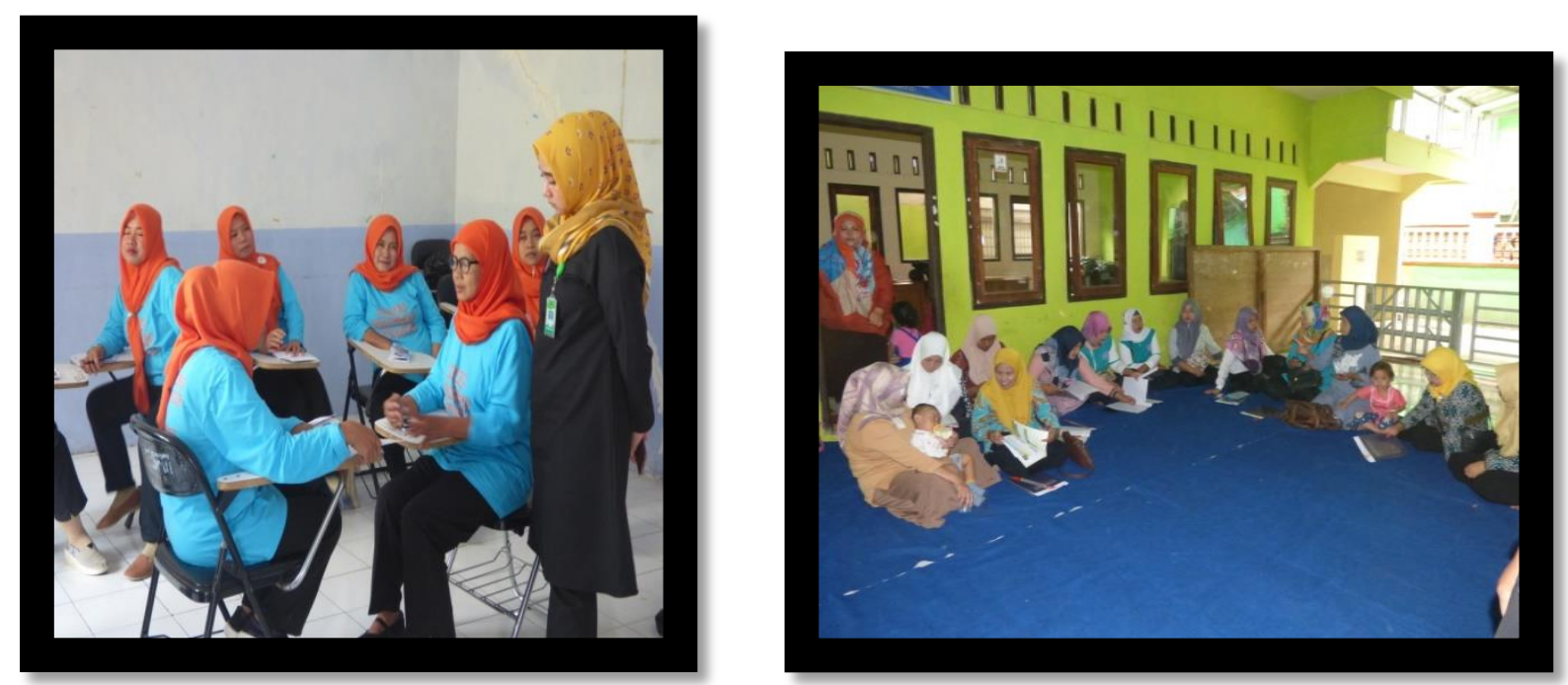